\title{
Removal of bacteria by clinoptilolite rich mineral and its surfactant modified forms
}

\author{
Beyhan Cansever Erdogan · Semra Ulku
}

Published online: 23 May 2013

(c) Springer Science+Business Media New York 2013

\begin{abstract}
Batch experiments were carried out to understand the potential values of clinoptilolite rich mineral and its surfactant modified forms in the removal of Grampositive and Gram-negative bacteria. Zeta potential and Fourier Transform IR analysis were performed to explain the possible interactions between the bacteria and the zeolite samples. The results revealed that hydrogen bonding was significant mechanism in the removal of bacteria with clinoptilolite rich mineral and anionic surfactant modified clinoptilolite rich mineral whereas both attractive electrostatic forces and hydrogen bonding were dominant mechanism in the removal of bacteria with cationic surfactant modified clinoptilolite rich mineral. Cationic and anionic surfactant modified clinoptilolite rich mineral are promising materials in removal of bacteria studies.
\end{abstract}

Keywords Bacteria - Clinoptilolite rich mineral . Surfactant $\cdot$ Modification

\section{Introduction}

Bacteria, one of the most important pathogenic microorganisms, are classified as "Gram-positive" and "Gramnegative" bacteria. The basic distinction between Grampositive and Gram-negative bacteria is the nature of the cell wall constituents. Gram-positive bacteria cell wall consists of a single $20-80 \mathrm{~nm}$ thick peptidoglycan layer and it is composed of peptidoglycan and teichoic acid

\section{B. C. Erdogan $(\bowtie) \cdot$ S. Ulku}

Chemical Engineering Department, Faculty of Engineering, Izmir Institute of Technology, Gulbahce Koyu, 35430 Urla, Izmir, Turkey

e-mail: beyhancansever@iyte.edu.tr which is connected to either peptidoglycan itself by a covalent bond with six hydroxyl of $N$-acetylmuramic acid (NAM) or to plasma membrane lipids which is called as lipoteichoic acids [1]. These acids which exist in only Gram-positive bacteria introduce more functional group into the peptidoglycan layer. On the other hand, the outer cell wall surface of Gram-negative bacteria consist of 2-7 nm thin peptidoglycan layer and outer cell membrane structure which contains phospholipids, lipopolysaccharides, enzymes and other proteins [1]. Some bacteria are beneficial in the food production, digestion in ruminant animal, decay of dead plant and animal. Some of them are harmful and cause healthcare associated infections. For example, $P$. aeruginosa is responsible for the mortality in cystic fibrosis [2] and S. epidermidis is the major cause of urinary tract infections, pneumonia, mastitis, phlebitis and meningitis. Because of their negative effects on human health, the studies on removal of bacteria have gained much attention. Recent studies showed that the process was complicated and the extent of removal was influenced by the material surface and bacterial properties [3]. Changing of those properties affects the contribution of electrostatic and non electrostatic forces which are responsible in the removal studies [4-7]. Corundum, quartz, hematite, goethite, kaolinite and montmorillonite, clinoptilolite rich mineral were used as adsorbent in the removal of bacteria studies [8-11].

Clinoptilolite rich mineral is a crystalline hydrated aluminosilicate with the framework structure composed of $\mathrm{AlO}_{4}$ and $\mathrm{SiO}_{4}$ tetrahedra, channels and cavities which are occupied by water and exchangeable cations such as $\mathrm{Na}^{+}$, $\mathrm{K}^{+}, \mathrm{Ca}^{2+}$ and $\mathrm{Mg}^{2+}$. Type of the exchangeable cations and their specific positions within the framework play an important role in ammonium removal [12-15], in heavy metal removal [16-27], in animal nutrition [28], in gas 
adsorption [29-34] in building and polymer industry [3538] as well as in biomedical applications [39-44]. Apart from these application fields, clinoptilolite rich mineral and its surfactant modified clinoptilolite rich mineral are also used in the removal of bacteria. For the removal of bacteria, clinoptilolite rich mineral is not as efficient as its metal exchanged and cationic surfactant modified forms. Clinoptilolite rich mineral modified in these ways has better removal performance than its natural form. Previous studies indicated that $\mathrm{Cu}^{2+}, \mathrm{Fe}^{3+}, \mathrm{Ni}^{2+}, \mathrm{Zn}^{2+}$ and $\mathrm{Ag}^{+}$exchanged clinoptilolite rich mineral samples were effective in the removal of Serratia marcescens, Pseudomonas aeuriginosa, Escherichia coli and Enterococcus faecalis [17, 45, 46] and cationic surfactant modified clinoptilolite rich mineral was promising material for the removal of E. coli, Bacillus subtilis and Giardia intestinalis [47-50]. However, the removal abilities of the cationic surfactant modified clinoptilolite rich minerals towards Staphylococcus aureus, Staphylococcus epidermidis and $P$. aeruginosa were unknown. Moreover, the removal of bacteria by anionic surfactant modified clinoptilolite rich mineral has not been subjected to study. In the present study, Gram-positive and Gram-negative bacteria removal performances of the clinoptilolite rich mineral and its surfactant modified forms were determined and the related mechanism was discussed.

\section{Materials and methods}

\subsection{Preparation of the zeolite and surfactant modified zeolite samples}

Clinoptilolite rich mineral samples (CLI), obtained from mineral deposits located in Manisa Gordes region, were prepared by the sample preparation method as given in our previous studies [51]. The particle size of the samples used in the experiment was in the range of $25-106 \mu \mathrm{m}$. In order to modify the clinoptilolite rich mineral samples, hexadecyltrimethylammonium bromide (HDTMA, ALFA) was used as cationic surfactant, whereas sodium dodecyl sulfate (SDS, MERCK) was used as anionic surfactant. Fifty milliliters of HDTMA solution of concentration $0.02 \mathrm{~mol} / \mathrm{L}$ was placed in a flask and $0.5 \mathrm{~g}$ of clinoptilolite rich mineral sample was added into the solution. Then, the flask was placed onto a magnetic stirrer and was stirred at $400 \mathrm{rpm}$ and $25{ }^{\circ} \mathrm{C}$ for $3 \mathrm{~h}$. The mixture was centrifuged at $1,000 \mathrm{rpm}$ for $10 \mathrm{~min}$. After centrifugation, the liquid part was removed and the solid part was washed three times with deionized water to remove the excess amount of cationic surfactant on the zeolite surface. The centrifugation procedure was repeated for three times under the same conditions. Finally, HDTMA modified forms was dried in an oven at $40{ }^{\circ} \mathrm{C}$ for $24 \mathrm{~h}$ and stored in desiccators for the further studies. Similar modification steps were applied for anionic surfactant modified clinoptilolite rich mineral using $0.03 \mathrm{~mol} / \mathrm{L}$ SDS. After modification step, cationic and anionic surfactant modified clinoptilolite rich mineral samples were labeled as CMCLI and AMCLI, respectively.

\subsection{Bacteria studies}

Escherichia coli (NRLL-B-3008) and P. aeuriginosa (ATCC- 27853) were chosen as Gram-negative bacteria whereas B. subtilis (NRLL-B-4378), S. aureus (ATCC29213) and S. epidermidis (ATCC-12228) were chosen as Gram-positive bacteria. Bacteria cell cultures were grown in $8 \mathrm{~mL}$ Mueller-Hinton Broth (Oxoid) at $37^{\circ} \mathrm{C}$ for $24 \mathrm{~h}$. At the end of $24 \mathrm{~h}$, cell cultures were centrifuged at $5,000 \mathrm{rpm}$ for $10 \mathrm{~min}$. After centrifugation, Mueller-Hinton broth was removed from the cell cultures. Then, the bacteria cell cultures were suspended in $10 \mathrm{~mL}$ phosphate buffer solution (PBS) which was prepared by mixing with $5 \mathrm{mM}$ disodiumhydrogen phosphate $\left(\mathrm{Na}_{2} \mathrm{HPO}_{4}\right)$ (Riedel-de Häen, 304271), $5 \mathrm{mM}$ sodiumhydrogen phosphate monohydrate $\left(\mathrm{NaH}_{2} \mathrm{PO}_{4} \cdot \mathrm{H}_{2} \mathrm{O}\right)$ (Sigma S071) and $150 \mathrm{mM} \mathrm{NaCl}$ (Riedel-de Häen, 31434). After that, the suspended solution was vortexed to obtain homogeneous distribution of bacteria cell cultures in PBS solution ( $\mathrm{pH}$ 7.4). Two bacteria cell culture groups were prepared and studied to understand the effect of the clinoptilolite rich mineral and its surfactant modified form on the bacteria cell concentrations. The first group contained only bacteria cell cultures and this group was called as "control group" and coded with "C". The second group contained zeolite samples and bacteria cell cultures and this group was called as "bacteria cell culture + zeolite samples" and coded with "Z". $0.1 \mathrm{~g}$ zeolite samples were added into $10 \mathrm{~mL}$ PBS solution $(\mathrm{pH}$ 7.4) and then the $\mathrm{C}$ and $\mathrm{Z}$ groups were kept in an incubator at $37^{\circ} \mathrm{C}$ for $1 \mathrm{~h}$; thereafter PBS solution was refreshed. After PBS refreshing, those two groups were placed in a thermostat shaker $\left(37{ }^{\circ} \mathrm{C}, 2 \mathrm{~h}\right)$. This procedure was repeated for three times under the same conditions. Finally, PBS was removed and the samples were dried at $37{ }^{\circ} \mathrm{C}$ for $24 \mathrm{~h}$. The details of the experimental procedure are given in Fig. 1.

In each step, bacteria concentrations of cell cultures for $\mathrm{C}$ and $\mathrm{Z}$ groups were measured against time using Viable Cell Count method. In this method, serial dilution procedure was used. In the procedure, $1 \mathrm{~mL}$ from each sample was added to $9 \mathrm{ml}$ peptone water solution. At the end of the serial dilution, $1 \mathrm{~mL}$ sample was added to a sterile Petri dish and then melted Mueller-Hinton agar (Merck) was poured in and mixed with sample. After drying of agar, Petri dishes were placed into incubator at $37^{\circ} \mathrm{C}$. The numbers of colonies were counted to calculate the bacteria cell concentration. All experiments were repeated three times to confirm the results. 


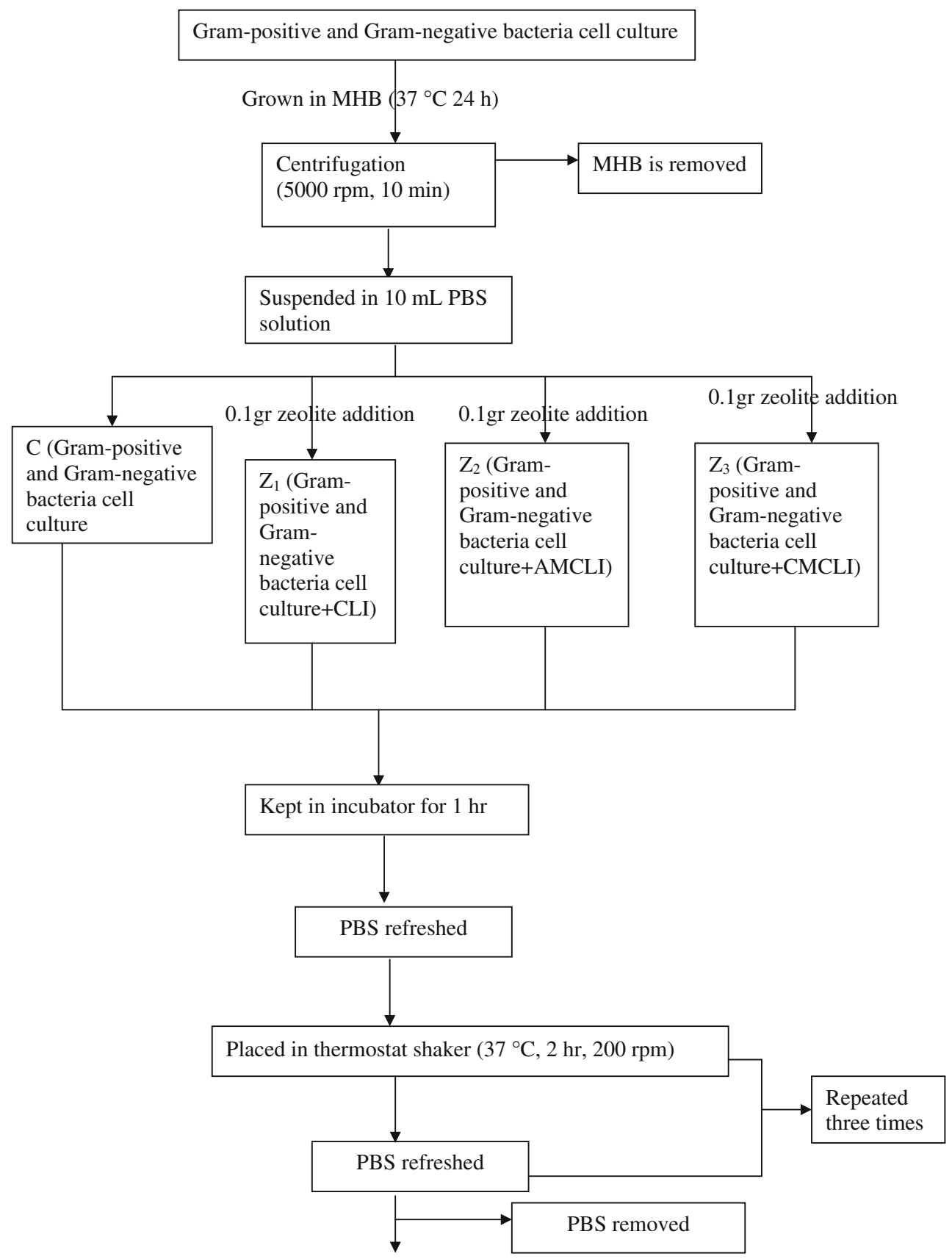

Fig. 1 The details of the experimental procedure used in bacteria studies

\subsection{Characterization of the samples}

Crystalline morphology of the samples was investigated by Philips XL30S model Scanning Electron Microscope. Identification of the crystalline species present in the samples was established using a Philips X'Pert Pro Diffractometer $\left(2 \theta=5^{\circ}-80^{\circ}\right)$. The clinoptilolite content of the zeolite sample was determined by the quantitative analysis method which has been proposed by Nakamura et al. [52]. The functional groups on the samples were characterized by Fourier Transform IR (FTIR, Shimadzu8201). Chemical composition of the samples was determined by Inductively Coupled Plasma Atomic Emission Spectrometer (Varian ICP-AES 96). The pore size distributions of the samples were estimated by MicromeriticsASAP 2010. The samples were dried at $150{ }^{\circ} \mathrm{C}$ for $4 \mathrm{~h}$. The dried samples were degassed at $350{ }^{\circ} \mathrm{C}$ for $24 \mathrm{~h}$ [53]. Measurements were performed at $77 \mathrm{~K}$ by nitrogen as adsorptive. The contribution of the electrostatic interaction between the bacteria and the zeolite samples were 
determined by zeta potential (Zeta meter 3.0). In the analysis, the zeolite samples were dispersed in $20 \mathrm{~mL}$ PBS solution ( $\mathrm{pH}$ 7.4).

\subsection{Surfactant configuration on the clinoptilolite rich mineral surface}

In order to identify the types of surfactant configuration (monolayer or bilayer) on the clinoptilolite rich mineral surface, packing areas for the HDTMA and SDS on clinoptilolite rich mineral were calculated from the following equation $[54,55]$.

Parking Area $=\frac{10^{20}}{\Gamma_{\max } A}$

where $\Gamma_{\max }$ is the adsorption density at the plateau region and $A$ is the Avogadro Number $\left(6.02 \times 10^{23}\right)$. The values of adsorption density at plateau region $\left[\Gamma_{\max }\right]$ were determined from the plots of adsorption densities of clinoptilolite rich mineral-HDTMA and clinoptilolite rich mineralSDS versus concentration graph.

The values of surface coverage were found from the ratio of the cross sectional area of surfactant molecule and packing areas for the surfactant on clinoptilolite rich mineral $[55,56]$. These values gave the idea about the surfactant configuration on the clinoptilolite rich mineral surface.

\section{Results and discussion}

\subsection{Characterization of zeolite after cationic} and anionic surfactant modification

SEM micrographs of clinoptilolite rich mineral and its surfactant modified forms are shown Fig. 2a-c. Thin platy crystals which resemble to the clinoptilolite crystals were observed in Fig. 2a. As seen in Fig. 2b-c, the clinoptilolite crystal structure was covered with the cationic and anionic surfactant after the modification. As a result of this, organic layer was formed on the clinoptilolite rich mineral surface $[57,58]$. XRD patterns of the clinoptilolite rich mineral and its surfactant modified forms are given in Fig. 3. XRD characteristic peaks of the clinoptilolite rich mineral were observed at $2 \theta=9.76^{\circ}, 22.23^{\circ}$ and $30.05^{\circ}$ and the clinoptilolite content of the sample was found to be $90 \%$ [51]. After modification with cationic surfactant, the major peaks of clinoptilolite mineral were unchanged and only the intensities of these peaks were decreased after the modification step [57-59]. However, not only the intensities of main peaks of clinoptilolite mineral were decreased but also additional two new peaks $\left(5.6^{\circ}\right.$ and $\left.8.7^{\circ}\right)$ were observed after the modification with the anionic surfactant. Both changes in XRD patterns pointed out the attachment of cationic and anionic surfactant on the clinoptilolite rich mineral surface. FTIR results of the clinoptilolite rich mineral and its surfactant modified forms are shown in Fig. 4. Characteristic bands of the clinoptilolite rich mineral related to $\mathrm{T}-\mathrm{O}$ stretching, $\mathrm{T}-\mathrm{O}$ bending, $\mathrm{OH}$ stretching, hydrogen bonding of water and water bending were observed at 1,085, 476, 3,672, 3,477 and $1,672 \mathrm{~cm}^{-1}$, respectively. After the modification with the cationic surfactant (HDTMA), two new bands were appeared at 2,937 and $2,860 \mathrm{~cm}^{-1}$. These bands were related to the asymmetric and symmetric $\mathrm{C}-\mathrm{H}$ stretching of methylene groups [60-62]. Additionally, four new bands were observed after modification with anionic surfactant (SDS). Bands observed at 2,924, 2,855, 1,214 and $1,467 \mathrm{~cm}^{-1}$ were assigned to the asymmetric and symmetric $\mathrm{C}-\mathrm{H}$ stretching of methylene groups, stretching modes of sulphonic acid group present in SDS and $\mathrm{C}-\mathrm{H}$ bending in $\mathrm{CH}_{3}$. The new band formation after the cationic and anionic surfactant modification indicated the presence of cationic and anionic surfactants on the clinoptilolite rich mineral surface. The pore size distributions of the clinoptilolite rich mineral and its surfactant modified forms are given in Fig. 5. The results indicated that pore sizes distributions of the samples were in the range of $25-110 \mathrm{~A}^{\circ}$. Regarding the pore size distributions, the samples have a mesoporous structure.

The chemical compositions of the clinoptilolite rich mineral, anionic and cationic surfactant modified forms are presented in Table 1. As shown in this table, the clinoptilolite rich mineral sample was identified as potassium clinoptilolite rich mineral. $\mathrm{SiO}_{2} / \mathrm{Al}_{2} \mathrm{O}_{3}$ ratios (wt $\%$ ) of the samples were calculated as 5.16, 5.21 and 5.29 for clinoptilolite rich mineral, cationic surfactant modified form and anionic surfactant modified form, respectively.

The graphs of adsorption densities of clinoptilolite rich mineral-HDTMA and clinoptilolite rich mineral-SDS versus concentration are given in Figs. 6 and 7. The results indicated that the values of adsorption density at plateau region for clinoptilolite-HDTMA and clinoptilolite-SDS were found as $1 \times 10^{-4}$ and $7 \times 10^{-5} \mathrm{~mol} / \mathrm{m}^{2}$, respectively. The parking areas of HDTMA and SDS on the clinoptilolite rich mineral were found to be $16.61 \mathrm{~A}^{\circ 2} /$ molecule and $23 \mathrm{~A}^{\circ 2} /$ molecule, respectively. The cross sectional areas of HDTMA and SDS molecules were reported as $37.82 \mathrm{~A}^{\circ 2} /$ molecule [55] and $53 \mathrm{~A}^{\circ 2} /$ molecule [63], respectively. The values of surface coverage were found to be $\sim 2.0$ for each surfactant. The results indicated that a bilayer surfactant configuration was formed on the clinoptilolite rich mineral surface after modification with HDTMA and SDS.

\subsection{Removal of bacteria}

The changes in Gram-positive and Gram-negative bacteria cell concentration before and after the addition of the 


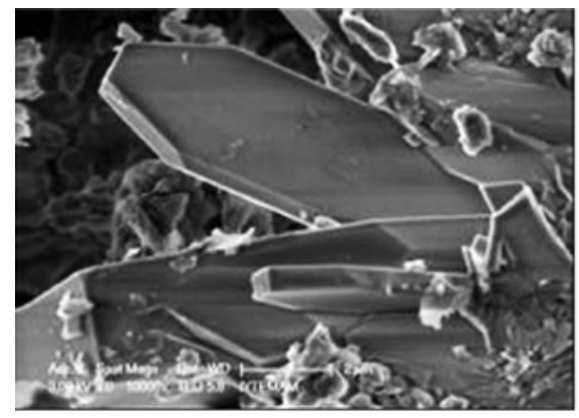

(a)

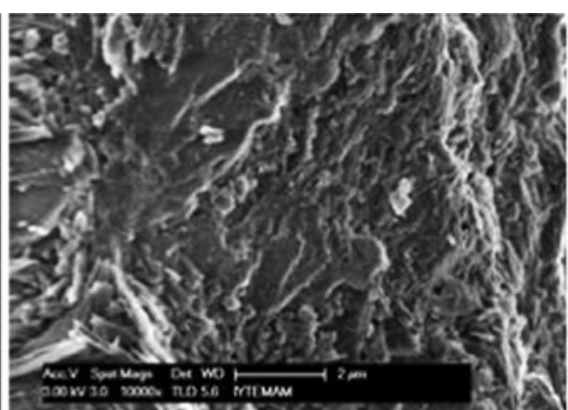

(b)

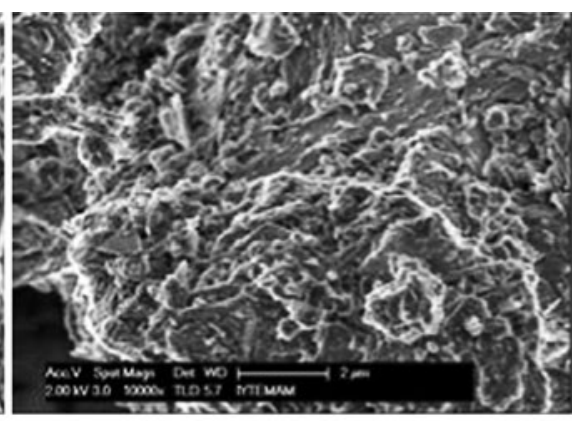

(c)

Fig. 2 SEM micrographs of a CLI, b CMCLI c AMCLI

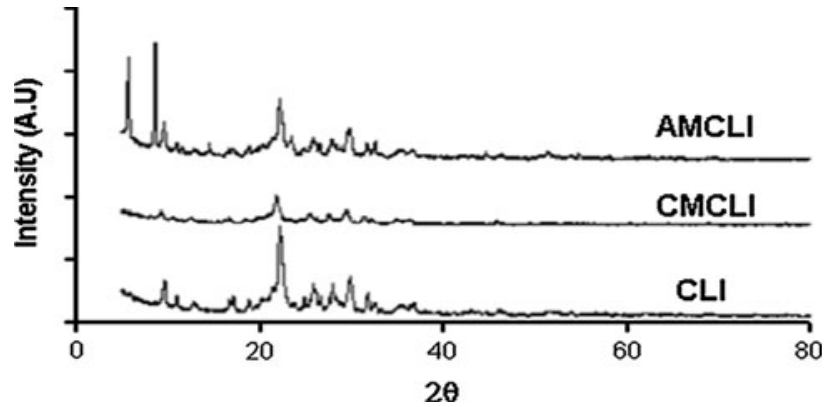

Fig. 3 X-Ray Diffraction patterns of CLI, CMCLI and AMCLI

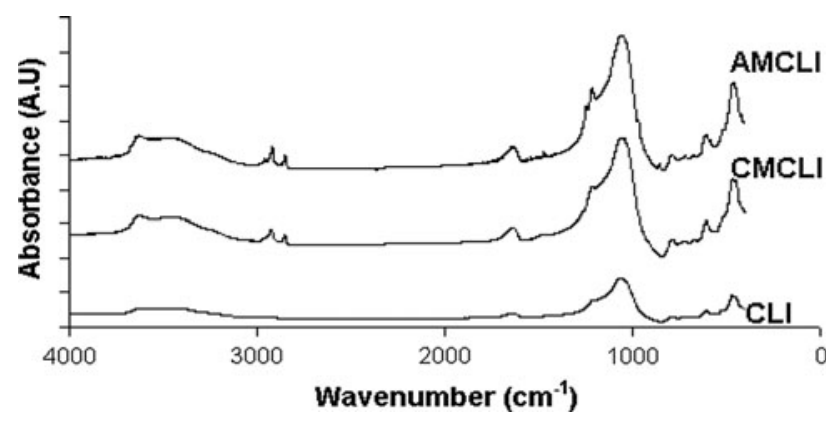

Fig. 4 FTIR results of CLI, CMCLI and AMCLI

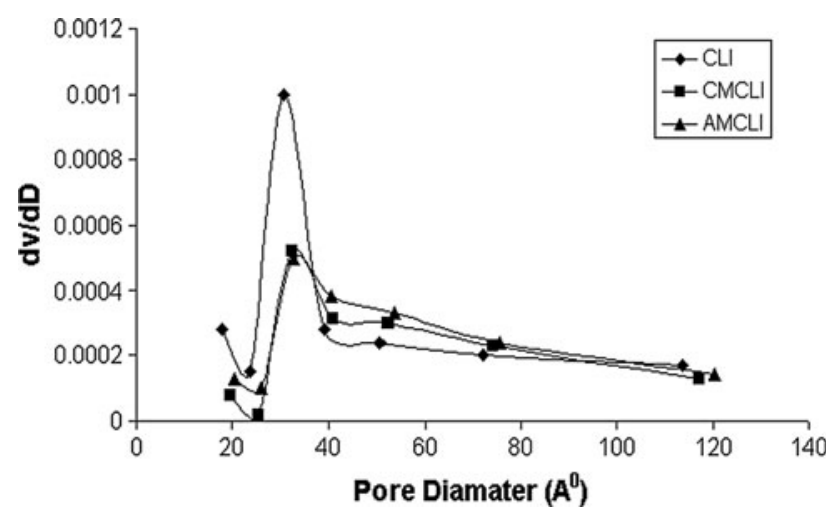

Fig. 5 Pore size distribution of the CLI, CMCLI and AMCLI
Table 1 Chemical compositions of CLI, CMCLI and AMCLI (wt\%)

\begin{tabular}{lccc}
\hline Oxides $(\%)$ & CLI & AMCLI & CMCLI \\
\hline $\mathrm{SiO}_{2}$ & 65.1 & 66.7 & 67.7 \\
$\mathrm{Al}_{2} \mathrm{O}_{3}$ & 12.6 & 12.8 & 12.8 \\
$\mathrm{Fe}_{2} \mathrm{O}_{3}$ & 1.42 & 0.89 & 0.62 \\
$\mathrm{~K}_{2} \mathrm{O}$ & 3.93 & 0.99 & 0.8 \\
$\mathrm{Na}_{2} \mathrm{O}$ & 0.92 & 2.88 & 2.4 \\
$\mathrm{CaO}$ & 1.92 & 0.88 & 0.7 \\
$\mathrm{MgO}$ & 0.85 & 0.68 & 0.52 \\
$\mathrm{H}_{2} \mathrm{O}$ & 13.4 & 14.4 & 14.6 \\
$\mathrm{Sum}$ & 100.1 & 100.2 & 100.1 \\
\hline
\end{tabular}

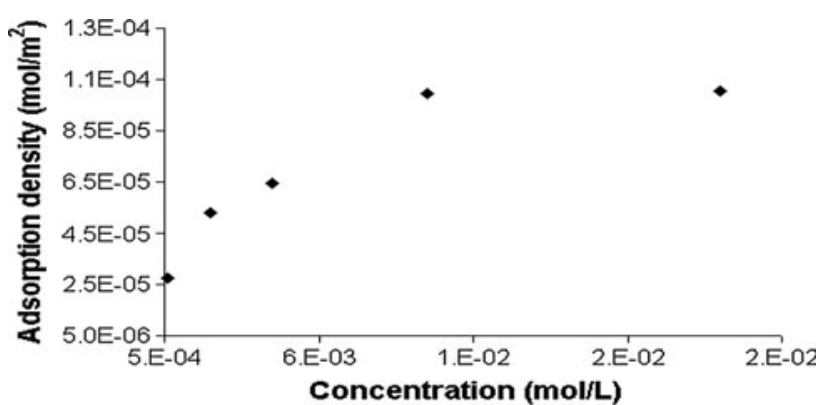

Fig. 6 The adsorption density versus concentration graph for clinoptilolite-HDTMA

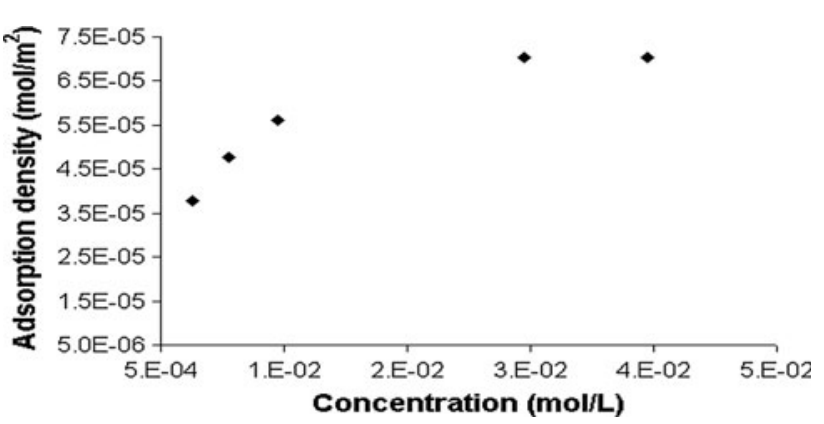

Fig. 7 The adsorption density versus concentration graph for clinoptilolite-SDS 
clinoptilolite rich mineral are given in the Table 2. The results indicated that bacteria cell concentration slightly changed with the addition of the clinoptilolite rich mineral. Tables 3 and 4 show Gram-positive and Gram-negative bacteria cell concentration results before and after the addition of the cationic and anionic surfactant modified clinoptilolite rich mineral. The results showed that bacteria cell concentration significantly changed with the addition of the cationic or anionic surfactant modified forms. By comparing bacteria concentration level against control, decrease levels in bacteria concentrations were found in the order of $1-10^{2}$ for the clinoptilolite rich mineral, $10^{2}-10^{4}$ for the anionic modified clinoptilolite rich mineral and $10^{3}-10^{5}$ for the cationic modified clinoptilolite rich mineral. Previous studies related to the surfactants indicated that cationic and anionic surfactants have been widely used as disinfectants because of their antimicrobial properties [64-70]. McDonnell and Russell [66] stated that cationic surfactant's mode of action was attributed to its positive charge, which formed an electrostatic bond with negatively charged sites on bacteria cell walls. Those electrostatic bonds created stresses in the bacteria cell wall, leading to cell lysis and disruption of cell-wall permeability [69]. The existence of anionic surfactant interfered with cell wall integrity and induced cell lysis by penetrating the outer and cytoplasmic membrane [69, 70]. As mentioned before, clinoptilolite rich mineral was not efficient in reducing the bacteria cell concentration. The incorporation of the cationic or anionic surfactants onto clinoptilolite rich mineral provided the antimicrobial property. This property enabled it to be used in removal of bacteria studies.
The performances of clinoptilolite rich mineral, cationic and anionic clinoptilolite rich mineral were founding the order of $S$. aureus $>S$. epidermidis $>B$. subtilis $>$ E. coli $>P$. aeruginosa. Higher reduction of Gram-positive bacteria was observed when compared to Gram-negative bacteria. This is explained by the nature of the cell wall constituents of bacteria. Secondary polymers (teichoic acid) which are only present on the Gram- positive bacteria cell wall structure enhanced the interaction between the bacteria and the sorbents.

\subsection{Characterization of zeolite after removal of bacteria}

Representative FTIR spectra of the cationic surfactant modified clinoptilolite rich mineral after $E$. coli loading is given in Fig. 8. The results indicated that the band shift in the water molecules and methylene groups on the cationic modified clinoptilolite rich mineral was observed after bacteria attachment. Similar band shift was observed with clinoptilolite rich mineral and anionic surfactant modified clinoptilolite rich mineral form after bacteria attachment. The band shifts in water molecules and methylene groups on the zeolite samples were indication of the existence of hydrogen bonding. The results implied that hydrogen bonding was the significant mechanism in the removal of bacteria with clinoptilolite rich mineral, anionic surfactant modified clinoptilolite rich mineral and cationic surfactant modified clinoptilolite rich mineral samples.

Table 2 The changes in the bacteria concentration before and after the addition of the clinoptilolite rich mineral

\begin{tabular}{|c|c|c|c|c|c|}
\hline \multirow[t]{2}{*}{ Bacteria Concentration $(\mathrm{CFU} / \mathrm{mL})$} & \multicolumn{5}{|l|}{ Time (h) } \\
\hline & 0 & 1 & 3 & 5 & 7 \\
\hline \multicolumn{6}{|l|}{ E. coli } \\
\hline $\mathrm{C}$ & $1.8 \pm 0.1 \times 10^{9}$ & $10.5 \pm 0.1 \times 10^{8}$ & $8.0 \pm 0.6 \times 10^{8}$ & $4.2 \pm 1.1 \times 10^{8}$ & $2.2 \pm 1.5 \times 10^{8}$ \\
\hline $\mathrm{Z}_{1}$ & $1.8 \pm 0.1 \times 10^{9}$ & $9.2 \pm 0.8 \times 10^{8}$ & $2.0 \pm 0.3 \times 10^{8}$ & $2.7 \pm 0.4 \times 10^{7}$ & $5.5 \pm 0.5 \times 10^{7}$ \\
\hline \multicolumn{6}{|l|}{ P. aeruginosa } \\
\hline $\mathrm{C}$ & $2.0 \pm 0.1 \times 10^{9}$ & $11.4 \pm 0.1 \times 10^{8}$ & $8.5 \pm 0.3 \times 10^{8}$ & $4.6 \pm 0.5 \times 10^{8}$ & $2.5 \pm 0.2 \times 10^{8}$ \\
\hline $\mathrm{Z}_{1}$ & $2.0 \pm 0.1 \times 10^{9}$ & $10.7 \pm 0.1 \times 10^{8}$ & $6.6 \pm 0.6 \times 10^{8}$ & $3.5 \pm 0.4 \times 10^{8}$ & $1.2 \pm 0.5 \times 10^{8}$ \\
\hline \multicolumn{6}{|l|}{ S. epidermidis } \\
\hline $\mathrm{C}$ & $1.7 \pm 0.1 \times 10^{9}$ & $11.3 \pm 0.1 \times 10^{8}$ & $7.4 \pm 0.8 \times 10^{8}$ & $5.2 \pm 0.7 \times 10^{8}$ & $2.9 \pm 0.8 \times 10^{8}$ \\
\hline $\mathrm{Z}_{1}$ & $1.7 \pm 0.1 \times 10^{9}$ & $9.8 \pm 0.8 \times 10^{8}$ & $4.2 \pm 0.5 \times 10^{8}$ & $1.4 \pm 0.3 \times 10^{8}$ & $3.0 \pm 0.7 \times 10^{7}$ \\
\hline \multicolumn{6}{|l|}{ S. aureus } \\
\hline $\mathrm{C}$ & $1.7 \pm 0.1 \times 10^{9}$ & $10.5 \pm 0.7 \times 10^{8}$ & $8.2 \pm 0.9 \times 10^{8}$ & $5.4 \pm 0.7 \times 10^{8}$ & $2.9 \pm 0.8 \times 10^{8}$ \\
\hline $\mathrm{Z}_{1}$ & $1.7 \pm 0.1 \times 10^{9}$ & $6.3 \pm 0.6 \times 10^{8}$ & $2.4 \pm 0.3 \times 10^{8}$ & $1.2 \pm 0.5 \times 10^{8}$ & $2.7 \pm 1.3 \times 10^{7}$ \\
\hline \multicolumn{6}{|l|}{ B. subtilis } \\
\hline $\mathrm{C}$ & $2.4 \pm 0.1 \times 10^{8}$ & $1.9 \pm 0.1 \times 10^{8}$ & $9.2 \pm 1.2 \times 10^{7}$ & $3.5 \pm 0.6 \times 10^{7}$ & $2.6 \pm 0.4 \times 10^{7}$ \\
\hline $\mathrm{Z}_{1}$ & $2.3 \pm 0.1 \times 10^{8}$ & $1.0 \pm 0.1 \times 10^{8}$ & $4.5 \pm 0.9 \times 10^{7}$ & $7.3 \pm 0.9 \times 10^{6}$ & $4.8 \pm 1.2 \times 10^{6}$ \\
\hline
\end{tabular}

$C$ bacteria cell culture (control), $Z_{1}$ bacteria cell culture + clinoptilolite rich mineral 
Table 3 The changes in the bacteria concentration before and after the addition of the cationic surfactant modified clinoptilolite rich mineral Bacteria Concentration $(\mathrm{CFU} / \mathrm{mL}) \quad$ Time $(\mathrm{h})$

\begin{tabular}{lllll}
\hline 0 & 1 & 3 & 5 & 7
\end{tabular}

\begin{tabular}{|c|c|c|c|c|c|}
\hline \multicolumn{6}{|c|}{ E. coli } \\
\hline $\mathrm{C}$ & $1.7 \pm 0.1 \times 10^{9}$ & $10 \pm 0.5 \times 10^{8}$ & $8.6 \pm 0.6 \times 10^{8}$ & $4.6 \pm 0.4 \times 10^{6}$ & $1.4 \pm 0.5 \times 10^{6}$ \\
\hline $\mathrm{Z}_{2}$ & $1.7 \pm 0.2 \times 10^{9}$ & $2.0 \pm 0.7 \times 10^{6}$ & $8.3 \pm 1.0 \times 10^{5}$ & $1.5 \pm 0.6 \times 10^{5}$ & $7.7 \pm 1.5 \times 10^{4}$ \\
\hline \multicolumn{6}{|c|}{ P. aeruginosa } \\
\hline $\mathrm{C}$ & $2.0 \pm 0.1 \times 10^{9}$ & $10.7 \pm 0.1 \times 10^{8}$ & $8.4 \pm 0.6 \times 10^{8}$ & $4.6 \pm 0.4 \times 10^{8}$ & $2.5 \pm 0.5 \times 10^{8}$ \\
\hline $\mathrm{Z}_{2}$ & $2.1 \pm 0.1 \times 10^{9}$ & $4.0 \pm 1.6 \times 10^{7}$ & $3.2 \pm 1.7 \times 10^{6}$ & $2.8 \pm 0.6 \times 10^{5}$ & $2.3 \pm 0.8 \times 10^{5}$ \\
\hline \multicolumn{6}{|c|}{ S. epidermidis } \\
\hline $\mathrm{C}$ & $1.7 \pm 0.1 \times 10^{9}$ & $10.8 \pm 0.1 \times 10^{8}$ & $7.4 \pm 1.1 \times 10^{8}$ & $5.2 \pm 0.7 \times 10^{8}$ & $2.9 \pm 0.7 \times 10^{8}$ \\
\hline $\mathrm{Z}_{2}$ & $1.7 \pm 0.1 \times 10^{9}$ & $3.0 \pm 0.3 \times 10^{6}$ & $2.7 \pm 1.3 \times 10^{5}$ & $8.3 \pm 1.5 \times 10^{3}$ & $4.3 \pm 0.5 \times 10^{3}$ \\
\hline \multicolumn{6}{|c|}{ S. aureus } \\
\hline $\mathrm{C}$ & $1.9 \pm 0.1 \times 10^{9}$ & $11.5 \pm 0.1 \times 10^{8}$ & $8.2 \pm 1.0 \times 10^{8}$ & $5.6 \pm 0.7 \times 10^{8}$ & $2.4 \pm 0.7 \times 10^{8}$ \\
\hline $\mathrm{Z}_{2}$ & $1.8 \pm 0.1 \times 10^{9}$ & $1.3 \pm 1.5 \times 10^{6}$ & $3.2 \pm 1.3 \times 10^{4}$ & $7.3 \pm 1.6 \times 10^{3}$ & $3.0 \pm 1.6 \times 10^{\circ}$ \\
\hline \multicolumn{6}{|c|}{ B. subtilis } \\
\hline $\mathrm{C}$ & $2.4 \pm 0.2 \times 10^{8}$ & $1.8 \pm 0.1 \times 10^{8}$ & $9.0 \pm 1.2 \times 10^{7}$ & $2.8 \pm 0.9 \times 10^{7}$ & $1.9 \pm 0.4 \times 10^{7}$ \\
\hline $\mathrm{Z}_{2}$ & $2.3 \pm 0.2 \times 10^{8}$ & $3.0 \pm 1.4 \times 10^{5}$ & $8.7 \pm 1.5 \times 10^{3}$ & $3 \pm 1.0 \times 10^{3}$ & $1.5 \pm 0.5 \times 10^{2}$ \\
\hline
\end{tabular}

$C$ bacteria cell culture (control), $Z_{2}$ bacteria cell culture + cationic surfactant modified clinoptilolite rich mineral

\subsection{Proposed mechanism in the removal of bacteria}

Previous studies indicated that the electrostatic forces and non-electrostatic forces were responsible in the removal of bacteria with clay minerals $[4,7,11,71,72]$. The electrostatic force originates from the Columbic interaction between the two charged entities whereas the non-electrostatic ones come from the hydrogen bonding, van der Waals force and hydrophobic interactions. Repulsive and attractive electrostatic forces between the bacteria and surface of the material are resulted from the negative or positive surface charge on the bacteria and mineral surface. In this part, the proposed mechanism in the removal of bacteria was explained by taking into account electrostatic and non electrostatic forces.

Zeta potential and FTIR analysis were performed to understand the contribution of the electrostatic and the nonelectrostatic forces between the bacteria and the zeolite

Table 4 The changes in the bacteria concentration before and after the addition of the anionic surfactant modified clinoptilolite rich mineral

\begin{tabular}{|c|c|c|c|c|c|}
\hline \multirow[t]{2}{*}{ Bacteria concentration $(\mathrm{CFU} / \mathrm{mL})$} & \multicolumn{5}{|l|}{ Time (h) } \\
\hline & 0 & 1 & 3 & 5 & 7 \\
\hline \multicolumn{6}{|l|}{ E. coli } \\
\hline $\mathrm{C}$ & $1.6 \pm 0.1 \times 10^{9}$ & $9.8 \pm 0.8 \times 10^{8}$ & $8.7 \pm 0.6 \times 10^{8}$ & $4.4 \pm 0.5 \times 10^{6}$ & $1.2 \pm 0.5 \times 10^{6}$ \\
\hline $\mathrm{Z}_{3}$ & $1.7 \pm 0.2 \times 10^{9}$ & $2.7 \pm 1.5 \times 10^{7}$ & $3.7 \pm 1.5 \times 10^{6}$ & $7.3 \pm 1.5 \times 10^{5}$ & $5.7 \pm 1.3 \times 10^{5}$ \\
\hline \multicolumn{6}{|l|}{ P. aeruginosa } \\
\hline $\mathrm{C}$ & $2.0 \pm 0.1 \times 10^{9}$ & $9.7 \pm 0.1 \times 10^{8}$ & $8.4 \pm 1.1 \times 10^{8}$ & $4.2 \pm 0.4 \times 10^{8}$ & $2.2 \pm 0.5 \times 10^{8}$ \\
\hline $\mathrm{Z}_{3}$ & $2.1 \pm 0.1 \times 10^{9}$ & $6.2 \pm 0.8 \times 10^{8}$ & $4.0 \pm 0.7 \times 10^{7}$ & $4 \pm 0.5 \times 10^{6}$ & $2.8 \pm 0.8 \times 10^{6}$ \\
\hline \multicolumn{6}{|l|}{ S. epidermidis } \\
\hline $\mathrm{C}$ & $1.7 \pm 0.1 \times 10^{9}$ & $10.8 \pm 0.1 \times 10^{8}$ & $7.4 \pm 1.1 \times 10^{8}$ & $5.2 \pm 0.7 \times 10^{8}$ & $2.9 \pm 0.7 \times 10^{8}$ \\
\hline $\mathrm{Z}_{3}$ & $1.7 \pm 0.1 \times 10^{9}$ & $4.3 \pm 0.9 \times 10^{7}$ & $4.0 \pm 1.4 \times 10^{6}$ & $1.5 \pm 0.5 \times 10^{5}$ & $4.7 \pm 0.9 \times 10^{4}$ \\
\hline \multicolumn{6}{|l|}{ S. aureus } \\
\hline $\mathrm{C}$ & $1.9 \pm 0.1 \times 10^{9}$ & $11.3 \pm 0.1 \times 10^{8}$ & $8.2 \pm 1.1 \times 10^{8}$ & $5.6 \pm 0.7 \times 10^{8}$ & $2.4 \pm 0.7 \times 10^{8}$ \\
\hline $\mathrm{Z}_{3}$ & $1.8 \pm 0.1 \times 10^{9}$ & $1.2 \pm 0.8 \times 10^{6}$ & $5.0 \pm 1.3 \times 10^{5}$ & $2 \pm 0.5 \times 10^{4}$ & $1.2 \pm 1.2 \times 10^{4}$ \\
\hline \multicolumn{6}{|l|}{ B. subtilis } \\
\hline $\mathrm{C}$ & $2.4 \pm 0.2 \times 10^{8}$ & $1.9 \pm 0.2 \times 10^{8}$ & $9.2 \pm 1.2 \times 10^{7}$ & $3.5 \pm 0.9 \times 10^{7}$ & $2.2 \pm 0.6 \times 10^{7}$ \\
\hline $\mathrm{Z}_{3}$ & $2.3 \pm 0.2 \times 10^{8}$ & $6.0 \pm 1.2 \times 10^{6}$ & $8.7 \pm 1.5 \times 10^{4}$ & $1.1 \pm 1.5 \times 10^{4}$ & $9.7 \pm 1.5 \times 10^{3}$ \\
\hline
\end{tabular}

$C$ bacteria cell culture (control), $Z_{3}$ bacteria cell culture + anionic surfactant modified clinoptilolite rich mineral 


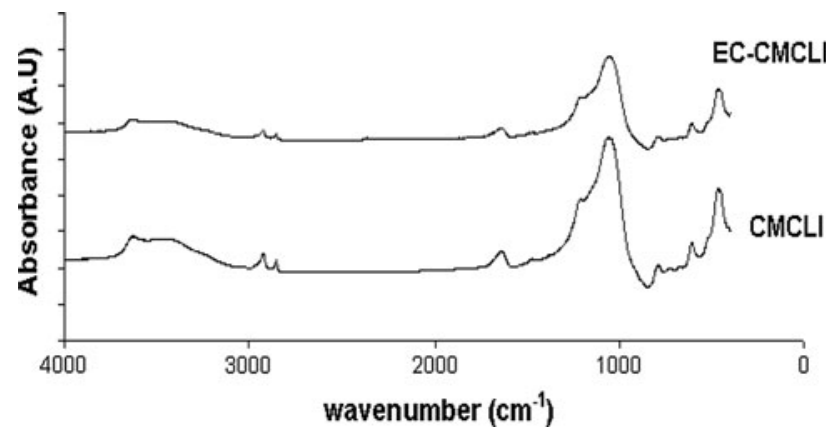

Fig. 8 FTIR results of CMCLI after E. coli loading

samples. Zeta potentials of the samples in the PBS solution ( $\mathrm{pH}$ 7.4) was measured to understand the contribution of the electrostatic forces. The surfaces of the Gram-positive and Gram-negative bacteria were in the PBS solution ( $\mathrm{pH} 7.4$ ) were reported as negatively charged [73, 74]. The zeta potential values of the samples were found as $-49.4,-58.5$ and 17.8 for the clinoptilolite rich mineral, anionic surfactant modified clinoptilolite rich mineral and cationic surfactant modified clinoptilolite rich mineral samples, respectively. The results indicated that there were repulsive electrostatic forces between bacteria-clinoptilolite rich mineral and bacteria-anionic surfactant modified clinoptilolite rich mineral since bacteria, clinoptilolite rich mineral and anionic surfactant modified clinoptilolite rich mineral had negative surface charges. On the other hand, there were attractive electrostatic forces between the bacteria and the cationic surfactant modified clinoptilolite rich mineral.

Fourier Transform IR analysis of the samples was performed to explain the non-electrostatic forces (hydrogen bonding) between bacteria and the zeolite samples. The existence of hydrogen bonding was supported by FTIR band shift in the water molecules and methylene groups on the zeolite samples.

Zeta potential and FTIR results implied that hydrogen bonding was the predominant mechanism in the removal of bacteria with clinoptilolite rich mineral and anionic surfactant modified clinoptilolite rich mineral whereas both attractive electrostatic forces and hydrogen bonding were responsible in the removal of bacteria with cationic surfactant modified clinoptilolite rich mineral. The highest removal of bacteria results with cationic modified clinoptilolite rich mineral was attributed to the summation of the electrostatic and the non electrostatic forces which enhanced the attachment of bacteria to the surface of the cationic surfactant modified clinoptilolite rich mineral.

\section{Conclusions}

The existence of successful modification of clinoptilolite rich mineral with cationic or anionic surfactant was supported by SEM, XRD and FTIR results. When the bacteria cell concentration results of the clinoptilolite rich mineral and its surfactant modified forms were compared, higher reduction in bacteria cell concentration was observed with cationic and anionic surfactant modified forms. The properties of clinoptilolite rich mineral related to removal of bacteria enhanced after modification with surfactants.

The extent of Gram-positive bacteria concentration reduction was significantly greater than Gram-negative bacteria concentration reduction. The existences of the electrostatic and the non electrostatic forces were evaluated by zeta potential and FTIR analysis. The results revealed that hydrogen bonding was significant mechanism in the removal of bacteria with clinoptilolite rich mineral and anionic surfactant modified clinoptilolite rich mineral whereas both attractive electrostatic forces and hydrogen bonding were dominant mechanism in the removal of bacteria with cationic surfactant modified clinoptilolite rich mineral.

As a summary, cationic and anionic surfactant modified clinoptilolite rich mineral have high potential in the reduction of bacterial concentration from wastewater.

Acknowledgments The authors are grateful to Turkish Republic Prime Ministry State Planning Organization (DPT-1998 K122130) for financial support. The authors thank to Prof. Hürriyet Polat for zeta potential analysis. The authors also thank to Prof. Devrim Balköse for her contribution and valuable discussion. The authors are also grateful to Center of Materials Research at Izmir Institute of Technology for their help during the characterization studies.

\section{References}

1. J. Wang, C. Chen, Biotechnol. Adv. 27, 195 (2009)

2. M.G. Hwang, H. Katayama, S. Ohgaki, Water Res. 41, 4097 (2007)

3. T.K. Stevik, K. Aa, G. Ausland, J.F. Hanssen, Water Res. 38, 1355 (2004)

4. X. Rong, Q. Huang, X. He, H. Chen, P. Cai, W. Liang, Colloids Surf. B 64, 49 (2008)

5. X. Rong, W. Chen, Q. Huang, P. Cai, W. Liang, Colloids Surf. B 80, 79 (2010)

6. L. Fang, P. Cai, P. Li, H. Wu, W. Liang, X. Rong, W. Chen, Q. Huang, J. Hazard. Mater. 181, 1031 (2010)

7. Y. Cao, X. Wei, P. Cai, Q. Huang, X. Rong, W. Liang, Colloids Surf. B 83, 122 (2011)

8. N. Yee, J.B. Fein, C.J. Daughney, Geochim. Cosmochim. Acta 64, 609 (2000)

9. N. Deo, K.A. Natarajan, P. Somasundaran, Int. J. Miner. Process. 62, 27 (2001)

10. D.A. Ams, J.B. Fein, H. Dong, P.A. Maurice, Geomicrobiol J. 21, $511(2004)$

11. D. Jiang, Q. Huang, P. Cai, X. Rong, W. Chen, Colloids Surf. B 54, 217 (2007)

12. N. Karapinar, J. Hazard. Mater. 170, 1186 (2009)

13. H. Huang, X. Xiao, B. Yan, L. Yang, J. Hazard. Mater. 175, 247 (2010)

14. B.C. Erdogan, S. Ulku, Appl. Clay Sci. 54, 217 (2011) 
15. N. Widiastuti, H. Wu, H.M. Ang, D. Zhang, Desalination 277, 15 (2011)

16. A.S. Sheta, A.M. Falatah, M.S. Al-Sewailem, E.M. Khaled, A.S.H. Sallam, Microporous Mesoporous Mater 61, 127 (2003)

17. A. Top, S. Ulku, Appl. Clay Sci. 27, 13 (2004)

18. V.J. Inglezakis, M.A. Stylianou, D. Gkantzou, M.D. Loizidou, Desalination 210, 248 (2007)

19. S. Kocaoba, Y. Orhan, T. Akyuz, Desalination 214, 1 (2007)

20. A. Dimirkou, M.K. Doula, Desalination 224, 280 (2008)

21. N.A. Oztas, A. Karabakan, O. Topal, Microporous Mesoporous Mater 111, 200 (2008)

22. S. Coruh, Desalination 225, 41 (2008)

23. T. Motsi, N.A. Rowson, M.J.H. Simmons, Int. J. Miner. Process. 92, 42 (2009)

24. A. García-Mendieta, M. Solache-Ríos, M.T. Olguín, Microporous Mesoporous Mater. 118, 489-495 (2009)

25. O. Can, D. Balkose, S. Ulku, Desalination 259, 17 (2010)

26. N. Lihareva, L. Dimova, O. Petrov, Y. Tzvetanova, Microporous Mesoporous Mater. 130, 32 (2010)

27. P. Misaelides, Microporous Mesoporous Mater. 144, 15 (2011)

28. F.A. Mumpton, PNAS 96, 3463 (1999)

29. G.A. Armenta, M.E.P. Iglesias, R.L. Ramos, Adsorpt. Sci. Technol. 21, 81 (2003)

30. M.W. Ackley, S.U. Rege, H. Saxena, Microporous Mesoporous Mater. 61, 25 (2003)

31. G. Narin, S. Yilmaz, S. Ulku, A chromatographic study of carbon monoxide adsorption on a clinoptilolite-containing natural zeolitic material. Chem. Eng. Commun. 191, 1525 (2004)

32. F.C. Ozkan, S. Ulku, Microporous Mesoporous Mater. 77, 47 (2005)

33. H. Faghihian, M. Talebi, M. Pirouzi, J. Iran. Chem. Soc. 5, 394 (2008)

34. M. Karsheva, E. Ivanova, Sep. Purif. Technol. 73, 429 (2010)

35. S. Atakul, D. Balkose, S. Ulku, J Vinyl Addit Tech 11, 47 (2005)

36. B.C. Erdogan, A.T. Seyhan, Y. Ocak, M. Tanoglu, D. Balkose, S. Ulku, J. Therm. Anal. Calorim. 94, 743 (2008)

37. H. Demir, M. Sipahioglu, D. Balkose, S. Ulku, J. Mater. Process. Technol. 195, 144 (2008)

38. S.A. Savrik, B.C. Erdogan, D. Balkose, S. Ulku, J. Appl. Polym. Sci. 116, 1811 (2010)

39. G. Rodriguez-Fuentes, M.A. Barrios, A. Iraizoz, I. Perdomo, B. Cedre, Zeolites 19, 441 (1997)

40. K. Pavelic, M. Hadzija, L. Bedrica, J. Pavelic, I. Dikic, M. Katic, M. Kralj, M.H. Bosnar, S. Kapitanovic, M. Poljak-Blazi, S. Krizanac, R. Stojkovic, M. Jurin, B. Subotic, M. Colic, J. Mol. Med. 78, 708 (2001)

41. K. Pavelic, M. Katic, V. Sverko, T. Marotti, B. Bosnjak, T. Balog, R. Stojkovic, M. Radacic, M. Colic, M. Poljak-Blazi, J Cancer Res Clin 128, 37 (2002)

42. G. Rodriguez-Fuentes, A.R. Denis, M.A. Barrios, A. Ivarez, A.I. Colarte, Microporous Mesoporous Mater. 94, 200 (2006)

43. G. Narin, C.B. Albayrak, S. Ulku, Appl. Clay Sci. 50, 560 (2010)

44. D. Demirbuker Kavak, S. Ulku, J. Porous Mater. (2012). doi: 10.1007/s10934-012-9602-1

45. D. Kallo, Rev. Mineral. Geochem. 45, 519 (2001)
46. Z. Milan, C.L. Pozas, M. Cruz, R. Borja, E. Sanchez, K. Ilangovan, Y. Espinosa, B. Luna, J Environ Sci Heal A 36, 1073 (2001)

47. D. Schulze, Trans. Am. Geophys. Union 83, 193 (2002)

48. R. Bowman, Microporous Mesoporous Mater. 61, 43 (2003)

49. C. Rust, D. Schulze-Makuch, R. Bowman, Zeolite 06-7 th International Conference on the Occurrence, Properties, and Utilization of Natural Zeolites (Socorro, New Mexico USA, 2006)

50. M. Abbaszadegan, P. Monteiro, R.N. Ouwens, H. Ryu, A. Alum, J Environ Sci Heal. A 41, 1201 (2006)

51. B.C. Erdogan, S. Ulku, Microporous Mesoporous Mater. 152, 253 (2012)

52. T. Nakamura, M. Ishikawa, T. Hiraiwa, J. Sato, Anal. Sci. 8, 539 (1992)

53. Y. Akdeniz, S. Ulku, J. Porous Mater 14, 55-60 (2007)

54. E. Sabah, M.S. Celik, Sep Sci Technol 37, 3081-3097 (2002)

55. B. Armagan, O. Ozdemir, M. Turan, M.S. Celik, J. Environ. Eng. 129, 709-715 (2003)

56. B. Armagan, O. Ozdemir, M. Turan, M.S. Celik, J. Chem. Technol. Biotechnol. 78, 725-732 (2003)

57. J. Warchol, P. Misaelides, R. Petrus, D. Zamboulis, J. Hazard. Mater. 137, 1410 (2006)

58. R.L. Ramos, A.J. Azuara, P.E.D. Flores, G.R.M. Coronado, J.M. Barron, M.S.B. Mendoza, Colloids Surf. A 330, 35 (2008)

59. H.Y. Wang, H.F. Huang, J.Q. Jiang, Sep. Purif. Technol. 80, 658-662 (2011)

60. M. Rozic, D.I. Sipusic, L. Sekovanic, S. Miljanic, L. Curkovic, J. Hrenovic, J. Colloid Interface Sci. 331, 295-301 (2009)

61. Y. Zeng, H. Woo, G. Lee, J. Park, Desalination 257, 102-109 (2010)

62. A. Nezamzadeh-Ejhieh, E. Afshari, Microporous Mesoporous Mater. 153, 267-274 (2012)

63. Q. Xu, T.V. Vasudevan, P. Somasundaran, J. Colloid Interface Sci. 142, 528-534 (1991)

64. W.K. Whitekettle, J. Ind. Microbiol. 7, 105-116 (1991)

65. T.E. Cloete, V.S. Brözel, V.S. Holya, Int. Biodeterior. Biodegradation 29, 299-341 (1992)

66. G. McDonnell, A.D. Russell, Clin. Microbiol. Rev. 12, 147-179 (1999)

67. L. Mereghetti, R. Quentin, N. Marquet-Van Der Mee, A. Audurier, Appl. Environ. Microbiol. 66, 5083-5086 (2000)

68. M. Shimizu, K. Okuzumi, A. Yoneyama, T. Kunisada, M. Araake, H. Ogawa, S. Kimura, Dermatology 204, 21-27 (2002)

69. M. Simoes, M.O. Pereira, I. Machado, L.C. Simoes, M.J. Vieira, J. Ind. Microbiol. Biotechnol. 33, 741-749 (2006)

70. E.A. Izano, H. Wang, C. Ragunath, N. Ramasubbu, J.B. Kaplan, J. Dent. Res. 86, 618-622 (2007)

71. Q. Fu, Y. Deng, H. Li, J. Liu, H. Hu, S. Chen, T. Sa, Appl. Surf. Sci. 255, 4551-4557 (2009)

72. L. Fang, P. Cai, P. Li, H. Wu, W. Liang, X. Rong, W. Chen, Q. Huang, J. Hazard. Mater. 181, 1031-1038 (2010)

73. B. Li, B.E. Logan, Coll Surf B 36, 81-90 (2004)

74. T.J. Kinnari, J. Esteban, N.Z. Martin-de-Hijas, O. SanchezMunoz, S. Sanchez-Salcedo, M. Colilla, M. Vallet-Regi, E. Gomez-Barrena, J. Med. Microbiol. 58, 132-137 (2009) 